\title{
EXPLORATION OF THE PRESALE PROPERTY MARKET IN CHINA FROM AN INSTITUTIONAL PERSPECTIVE
}

\author{
Barbara Y. P. LEUNG $1 \bowtie$ and Athenda S. C. MA ${ }^{2}$ \\ ${ }^{1}$ Department of Building and Real Estate, The Hong Kong Polytechnic University, Hong Kong, \\ China \\ E-mail: bsbleung@polyu.edu.hk \\ 2 Department of Building and Real Estate, The Hong Kong Polytechnic University, Hong Kong, \\ China \\ E-mail: athenda@hotmail.com
}

Received 26 February 2012; accepted 25 June 2012

\begin{abstract}
Presales have been used as a major financing mode for real estate development in China. However, there have been limited researches studying the roles of different real estate market players impacting on the efficiency of the property presales, in particular, on the issue of asymmetric information in the market. The paper adopted an institutional approach to study the problems latent in the presale property market. Semi-structured interviews with professionals and industry practitioners were conducted and the findings suggested that the lack of market information, pseudo policy objectives and confusing roles played by major market players are the root of the problems. Restructuring of the institutional arrangement in regard to the financial channels for capital, risk management on developers, custody of the presale proceeds and commitment of the regulatory authorities are necessary in enhancing the market efficiency.
\end{abstract}

KEYWRODS: Asymmetric information; Presale property; Institutions and regulations

REFERENCE to this paper should be made as follows: Leung, B. Y. P. and Ma, A. S. C. (2013) Exploration of the presale property market in China from an institutional perspective, International Journal of Strategic Property Management, 17(3), pp. 248-262.

\section{INTRODUCTION}

There have been dramatic institutional changes in the operation of residential property markets in recent years and the most notable change is the increasing use of property presales. Presale arrangement of uncompleted residential property has been adopted as the prime mode of sales by developers to alleviate financial burden, in particular, when the cost of debt-financing is high (Chan et al., 2008; Wong, 2012). Furthermore, presale is found to be an effective tool for developers to reduce their exposure of risk if the absorption rates in the market are below expectations by the time when the properties are completed (Buttimer et al., 2008; Wong, 2012). The presale mode is particularly popular in cities with high-rise apartments and large housing developments which require substantial development capital (Lai et al., 2004; Leung et al., 2007a; Cao et al., 2008; Zhong, 2005). However, presale property markets are commonly found highly inefficient due to the asymmetric information problem in trading uncompleted properties of which buyers do not have the chance to inspect the trading properties that are under construction, whereas the developers who undertake 
the construction must possess more information. When possession of information between the two parties in the trade is not aligned, the developer may have incentives to act against the interest of the buyers in the construction to generate a higher economic rent, thus moral hazard problem is created (Chau et al., 2007; Choy and Chau, 2006; Lai et al., 2004; Leung et al., 2007b, 2010).

In Mainland China, more than 50\% of newly constructed commercial residential properties were sold through presales and the ratio were even over $90 \%$ in some counties (Zhong, 2005), and problems generated from information asymmetry in the presale property market have also caused public concerns. There were cases that developers allied with property agents to hoard up properties and speculate on the prices by releasing fictitious information. It was common that when presale buyers collected their properties upon completion, problems such as smaller size of the properties, mismatch of fittings and finishes were found. The problems were so severe that in the 2004 Real Estate Financial Report, the People's Bank of China questioned whether the presale policy should be replaced by only sales of completed properties (Kalifa, 2005). A survey conducted by the Consumer's Association in Sichuan (Zhong, 2005) showed that 7,623 complaints filed from 2003 to 2005 in regard to sales of commercial properties, 6632 cases were related to presales, accounting for $91.3 \%$ of the total cases reported. Vice Minister of the China Ministry of Construction, Mr. Gi Ji, remarked that among the problems latent in the property market, those found in the presale process were the most (Research in China, 2008). Furthermore, according to the Real Estate Web Report, defaults of construction, poor built quality, unclear and exclusions of liabilities in the contracts were common risks that presale property buyers had to bear in Mainland China (Research in China, 2008). Considering the eminent problems brought about by presales, local government in Nanning attached to Guangxi Province suspended the presale policy in 2010 (TBW, 2010).
To tackle the problems, the central government promulgated a series of regulations aiming to remove mal-practices and improve the transparency of information. The most prominent one was the Regulations on Sales of Commodity Houses with Instant Marked Price promulgated in May 2011. It requires developers to apply the 'one house one price' policy that the price of each unit in the presales must be stated clearly in a price list when applying for the Presale Permit. The price list must also be published in the government's website and developers must strictly adhere to the price list when conducting presales. Despite the stern requirement, developers still found counter-measures by assigning a high-price when applying for the Presale Permit and then gave discount privately to individual buyer during presales making an illusion that the buyer was getting preferential treatment. As such, there were incidents that some buyers had paid a price relatively higher than the others on similar units in such "secret" deals, and in return, complaints were lodged by those paid a higher price. Similar problems were found not only in China, but also in many developed countries such as Singapore, Hong Kong, London and the U.S. with different extent of severity (Kalifa, 2005; Buang, 2006). A comparison of the different practices of property presales has been made in Leung et al. (2007a).

\section{EFFICIENCY OF PROPERTY PRESALES FROM INSTITUTIONAL PERSPECTIVE}

A number of researches have been conducted to study the efficiency of property markets, among them, the information efficiency approach has been found to be commonly employed (Brown and Matysiak, 2000). However, North (1990) pointed out that these studies were inadequate since they had isolated the use of information and failed to link this with issues arising from operation and allocative efficiency impacting the market. Since operation efficiency is concerned with the market processes and allocative efficiency refers to 
deployment of the resources, North (2005) advocated using the institutional perspective in assessing the market efficiency which takes into account of not only the information but also the specific characteristics of property itself and the operational features of market activity (Coase, 1998; D'Arcy and Keogh, 1997; North, 2005).

According to Keogh and D'Arcy (1999), the institutional regime of a property market constitutes the rules of games, governing the market activity including the ways of business interactions and knowledge acquisitions. The governance structure and institution structure might be partially beneficial to particular market participants of developers, government and consumers, depending on their bargaining powers. Developers, who possess monopoly control of property information behind their wealth-maximizing behavior, would naturally have the intention to induce biased competition on their advantage (North, 2005). North described developer as astute perceivers to any subtle institutional changes and convert the changes to their competitive advantages and eventually capitalizing on the imperfection arising from restricting the accessibility to information and delivery of "quality-imparted information" (D'Arcy and Keogh, 1998; North, 2005). The situation is more intense in presales market in which the level of severity of asymmetric information is much higher.

Along the growing importance of real estate development to economic stability of many areas (Lisheng, 2010; Tang, et al., 2006), the governments have adopted a prudent attitude to reign the market through the use of rules and regulations (Keogh and D'Arcy, 1999; Leung et al., 2010; North, 2005; Whitehead, 1983). However, implementation of the measures so as their effectiveness have been complicated by the institutional regime which include the social value of the community, the housing provision, economic and political changes. China, in a transitional market economy, have been criticized for the lack of full market rules and effective market enforcement in which the possession of guanxi (personal relationship) with government officials and market players is a determinant factor in a success of business (Tang et al., 2006; Leung et al. 2011; Wang and Chen, 2010). Incidents such as land hoarding and unethical presale practices could be attributed to the institutional factors which include ineffective enforcement of the regulatory measures against fraudulent practices, increasing lucrative profits that could be generated from property development, switching from spot-sales of completed properties to presales of uncompleted properties and poor accessibility of information in the presale market.

The paper aimed to examine the efficiency of the presale residential property market in Mainland China by exploring the market activities using an institutional approach, in particular, in addressing the questions of what the root of the problems latent in the institutional system are and the factors critical to the development of the presale property market. The data were collected from field investigation conducted in Shenzhen and Guangzhou between 2009 and 2011. These two cities were selected as they are among the first-tier cities in which the presale property markets are more mature compared to the lower-tier cities. The study started with a comprehensive review of the institutional features of the presale property market which included the financing channel, the administrative and regulatory system and the role played by different major market actors. An extensive survey of 120 semi-structured interviews with consumers, professionals and developers were then conducted to identify the root of the problems latent in the institutional system hindering a healthy operation of the presale market. Finally, the set of factors which are critical in enhancing the efficiency of the presale property market are recommended.

\section{INSTITUTIONAL FEATURES OF THE PRESALE PROPERTY MARKET IN MAINLAND CHINA}

\subsection{Financing channel}

Direct financing channel for real estate development in Mainland China is narrow and a majority of the fund comes from banks. Ac- 


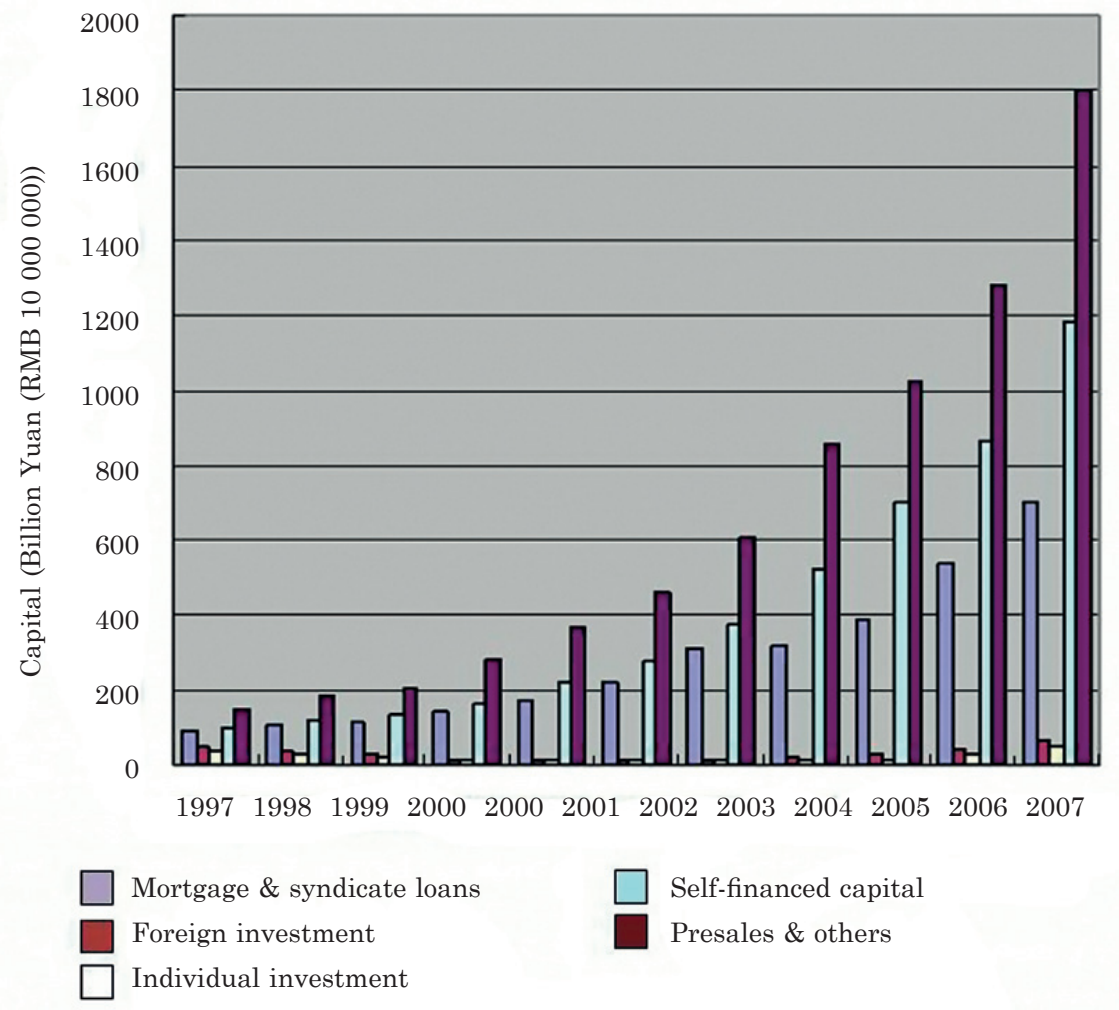

Figure 1. Capital for real estate development Source: Research in China (2008)

cording to the 2008 Real Estate Financial Report (Research in China, 2008), there were three main sources of development funds in real estate market, i.e., 35\% owned by developers; $18.4 \%$ from bank loans and $43.1 \%$ from proceeds collected from presales (Figure 1). In reality, the reliance on bank lending for the development should be much heavier, which could be as high as over 50\%, because most funds from developers were in fact personal borrowings from banks. Initial Public offering (IPO) for financing development capital is not easy as the government set up high performance threshold and stringent approval procedures. Most medium-and-small sized developers cannot reach the listing requirements except state-owned companies and super-size enterprises.

The growing importance of the use of presales as a major financing tool has been exacerbated by the macro-policies employed by the central government in tightening bank lending to property development and controlling foreign investment in real estate. In 2003, the People's Bank of China issued the notice which requires the reserve of developers to be not less than $30 \%$ of the gross investment of the project, the loans for land acquisition should not be more than $70 \%$ of the land appraised value and the repayment of the loan should not be more than 2 years. The Opinion on Regulating Foreign Investment in Real Estate Industry was promulgated in 2006 and the Administration was enacted in 2007 which restrict foreign investments from development of large tract land and spectacular projects. In 2008, the Circular for Strengthening Commercial Property Loan Management was released jointly by the People's Bank of China and the China Banking Regulatory Commission to raise the threshold of loans for residential property development. Given further shrinkage of bank loans and for- 
eign investment in China's real estate market, property developers are inevitably compelled to seek other financing channels.

Another incentive using presales is the boost of profit from saving arising from the reduced borrowing from banks. Wang (2005) reported a case of high-rise residential project built between 2003 and 2005, the presales were conducted in mid-2004. The total investment capital was RMB50 million of which $36 \%$ being developers' own funds, $20 \%$ from bank borrowings and 44\% from proceeds collected from presales. It was assessed that by using presales, the pre-tax return was much higher at $30 \%$, comparing to only $4 \%$ if the properties were sold only upon completion. The boost of profit was attributed to the substantial saving from bank interest.

\subsection{Administration system of the presale property market}

The administration system of the presale property market in China follows a top-down hierarchy shown in Figure 2.

At the highest level, the Ministry of Housing and Urban-Rural Development of the State Council centrally administers presales of commercial properties throughout the country through promulgation of law and policies, whereas the administrative departments of provinces and autonomous regions, municipalities and counties in charge of construction and/or real property administer and oversee presales of commercial properties within their administrative regions in accordance to the law and policies promulgated from the highest. Each administrative area has its local authority, mostly known as the Real Property Administration Department, to undertake property transaction registration and oversee the use of the presale proceeds (Cao, 2009).

Although administration of the presale property market follows a top-down hierarchical structure, the legislative system from the top is very slow in responding to the need of the local markets. This is on one hand due to the continental size of the country that socio-eco- nomic differences are wide among local areas, and thus provincial adjustments are required in implementation of the central policies. On the other hand, it is also the aim of the central government to maintain a set of flexible rules to deal with changes in both the social and economic environments. In order to promote the market-oriented real estate developments while recognizing local differences, the central government has delegated substantial fiscal autonomy to local governments since 1980s and tolerated a relatively high degree of selfinterest pursuit (Cao, 2009). This unique style of governance has provided huge incentives to local authorities to exploit resources and explore development opportunities in the local areas by adopting the doctrine of pragmatism. Although this approach helped exacerbate the economic growth of China, the central government has often become ineffective to ensure its policies and directive to be fully followed at the local level (Cao, 2009).

Many local governments pushed forward real estate developments without following the rules and procedures in order to generate lucrative revenue from sales of land and the associated taxes. For example, Collectively-Owned Land in villages in China is not allowed for construction of commercial buildings unless it has been converted into State-Owned Land. However, pilot projects were launched in Beijing in 2004 and Guangdong in 2005 to build commercial housings on collective land known as Town Title or Petty Title properties for buyand-sell. These buyers could not get a legitimate title of the properties since the use-rights on Collective-Owned Land could not be transferred. Informal statistics showed that these properties accounted for $20 \%$ of the total commercial properties in Beijing, 25\% to $30 \%$ in Xian, $40 \%$ to $50 \%$ in Shenzhen in 2007 (Wang and Chen, 2010) and the percentages have been growing. More recently, the Ministry of Land Resources noted the seriousness of the problem and asked for a halt of a petty title project in Wai Yau district of Beijing in 2010, similar incident happened again in 2011 in Ping Cheong district in 2011 (JRJ, 2011). 


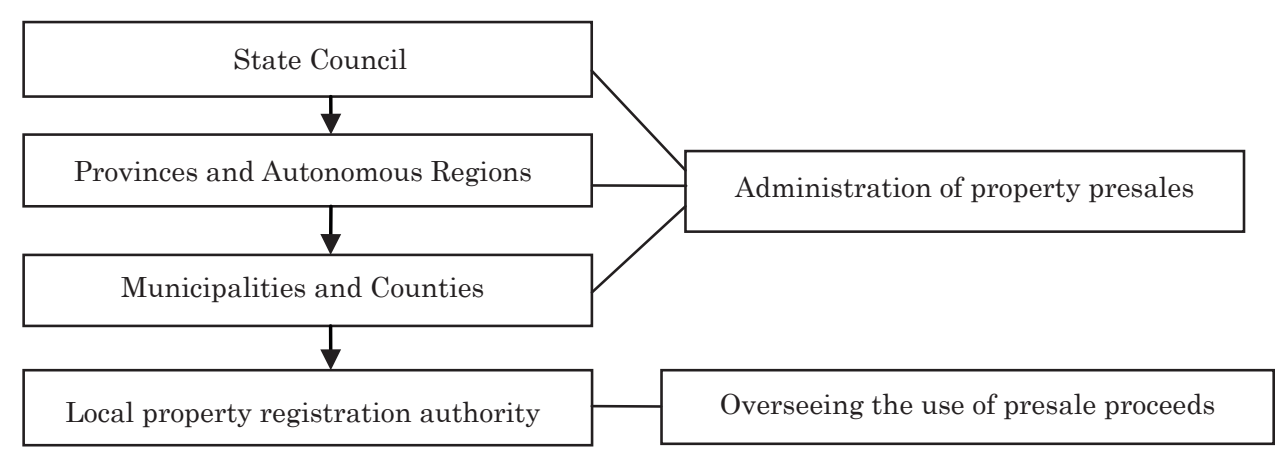

Figure 2. Top-down administration system of China's presale property market

\subsection{Fund management in real estate development projects}

The solid arrows shown in Figure 3 illustrate the flow of funds of a real estate development project under the formal institutional setting of the real estate market in China. To start a development project, developers are required to settle the payments for land acquisition such as the land grant fee and the stamp duty within a certain period of time, usually within one year after the purchase. The cost is usually around $30 \%$ to $40 \%$ of the total development cost, but the land use fees of some prime lands can reach as high as over $60 \%$. Once the permit for construction and other related documents are granted, the developer may apply for loans from banks for carrying out the construction (Gao, 2007). The size of loan would depend on the project size, the amount of capital required and the bargaining power of the developer. Presales permit can be applied upon completion of $2 / 3$ of the major buildings. The proceeds collected from presales shall be used to complete the construction and settle the other outstanding payments. The use of the funds shall be overseen by the local property registration authority until the delivery of the completed properties.

The fund-flow system above appeared straight-forward, however, the institutional arrangement has been complicated by not only the political interest but also the social belief and economic push which govern the ways of business interaction and knowledge acquisition in the market. As a result of ineffective central control and high autonomy delegated to local authorities, local real estate markets have been characterized by self-interest pursuit local policies, high power concentration and low information transparency (Cao, 2009). Although it is stipulated that land premium and land use fee must be settled within the period prescribed, developers who have guanxi with the local officials are able to defer the payment until completion of the project. It was reported that the pre-tax return of a real estate development was boosted from $33 \%$ to $111 \%$ attributed to both the deferred payment of land premium and use of presales to finance the upfront capital (Wong, 2012). In addition, many developers started presales before the Permit was granted, especially in non-first tier cities. In regard to the loans from banks, many developers chose to use part of the funds to purchase new land to start another project because they requested the construction companies (contractors) to make pre-payment on the construction (dotted arrows of Figure 3). Although this practice is prohibited by law, due to intense competition in the construction industry, many construction companies agreed with the pre-payment arrangement in order to secure the construction and be reimbursed when the properties were sold later. 


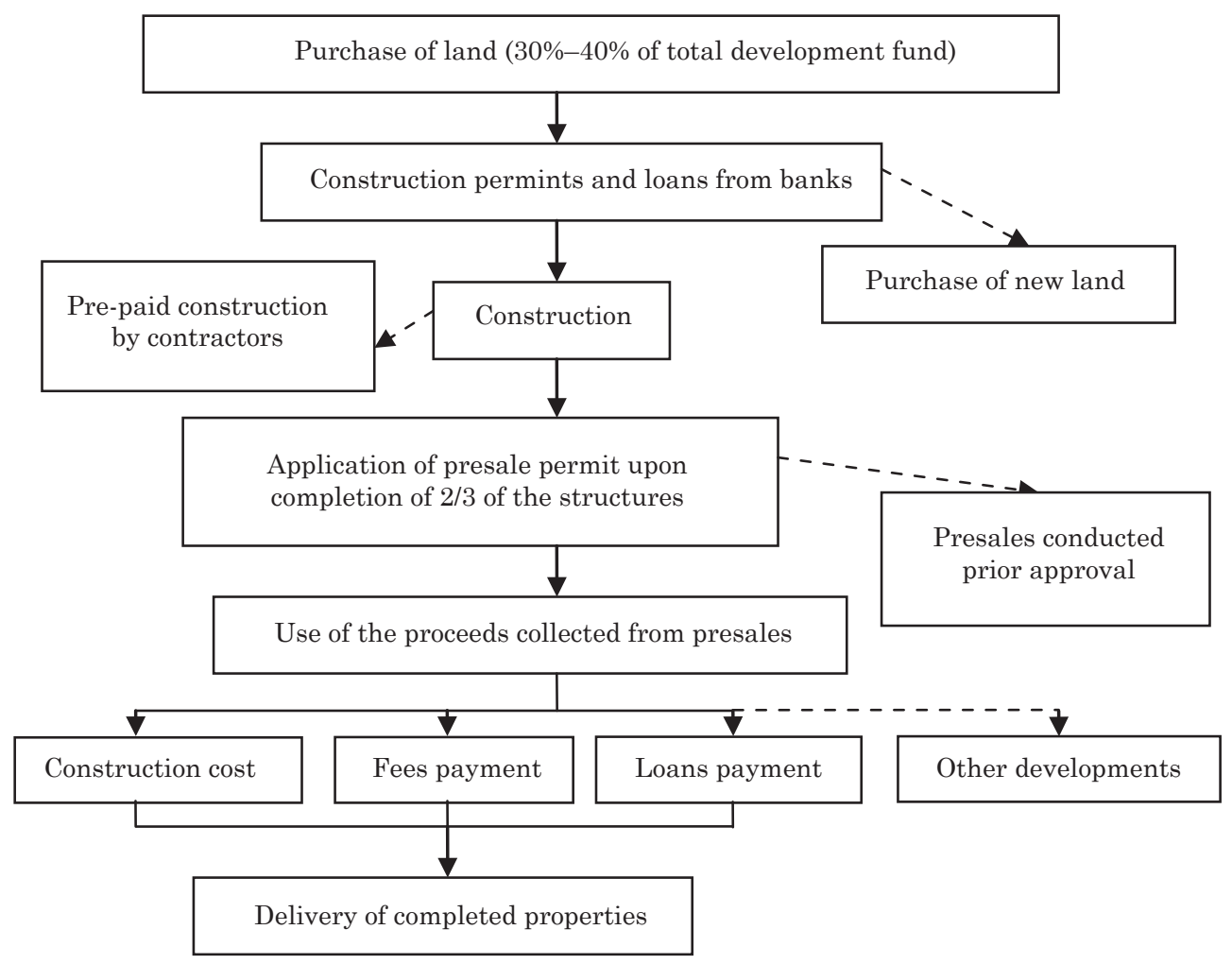

Figure 3. Flow of funds in a real estate development project

\subsection{Property presale regulatory system}

The property presale regulatory system in the Mainland follows a 3-level institutional hierarchy. At the top level, the central government promulgates central policies for the market players to adhere to as mentioned above. In the middle level, a three-pronged administration system is adopted by local authorities to regulate the market which includes the use of administrative measures, self-disciplinary undertakings and public supervision with the aim to protect the rights of buyers/consumers in the third level (Figure 4).

Level 1: Regulatory measures imposed by the central government. Different measures have been introduced by the central government to enhance the disclosure of information and enforcement of presale regulations. For example, the Administration of Urban Real Property Law was enacted by the Committee of National People's Congress to standardize the custody of commercial properties in 1994. Subsequently in the same year, the Administration of the Presale of Urban Commodity Procedures was issued to regulate the presale practices of uncompleted properties. In 2001, the Presale Procedures was further defined in the bylaws. They were revised again in 2004 which clearly stipulate that developers must not pre-sell commercial properties without Presale Permit and must adhere to the requirements stated in the Administration (Wang, 2008; Xu and Yang, 2006). In 2011, to further enhance information transparency, the requirement of Instant Marked Price was promulgated which requires developer to state the price of each unit when applying for a Presale Permit.

Level 2: Three-pronged approach in regulating local market. In the implementation stage in level 2, local governments adopt the three-pronged check-and-balance approach, i.e. through the local administrative meas- 


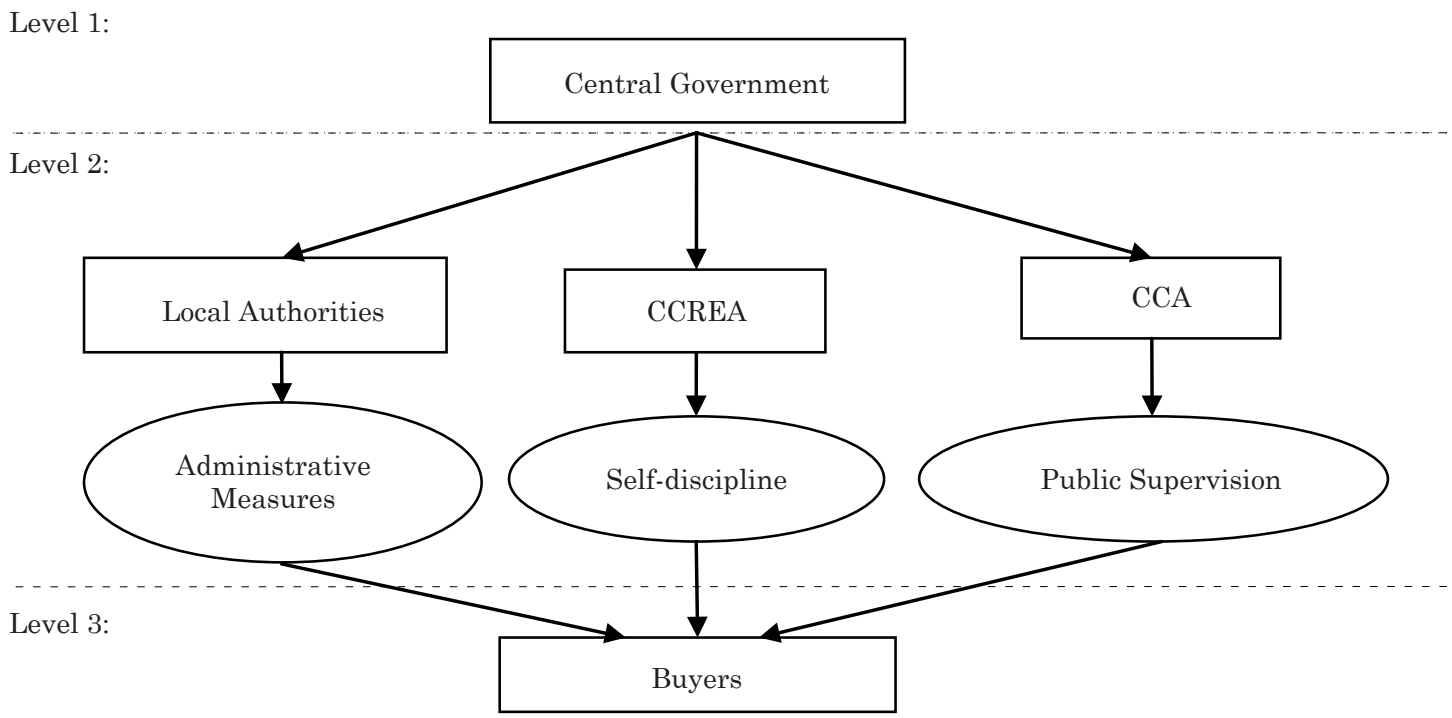

Figure 4. The 3-level institutional hierarchy of major market players

ures adapted from the regulations and policies promulgated by the central government, the China Commercial Real Estate Association (CCREA) and China Consumers' Association (CCA) can on one hand protect the interest of property buyers, and on the other hand, avoid fettering the market operation.

Local authorities are often given the discretionary power to adapt the rules and regulations promulgated by the central government to suit local circumstances. Although the discretionary power has enhanced the flexibility of local governments and ensure necessary government revenue, it brought along negative impacts such that preferential treatments given to developers when disputes arisen from property presales.

The CCREA is a national association approved by the government representing the commercial real estate industry with the aim to mitigate transaction costs in the market and to enhance the image of developers. It promulgates self-regulatory measures to guide its developer members on the conduct of property presales, however, the effectiveness is questionable since the key missions explicitly stated by the CCREA are "protecting the legal rights of its members, giving advice to government agencies in policy-making policies and representing the industry in liaising with local authorities" before protecting the interest of property buyers.

In regard to CCA, this is a monitoring institution overseeing the operation of the market and looking after the benefits of consumers. It aims to enhance consumers' rights within the legal framework. CCA has publicly criticized the unethical presale practices of developers in the mass media. They also meet the market participants, such as the CCREA, regularly to reflect the complaints made by the public and to look for remedial actions. However, CCA has not been delegated with legislative power to enforce the protection measures.

Level 3: Bargaining power of presale property buyers. The bargaining power of presale property buyers is related to access of accurate information, education and wealth of people. Problem of access to accurate information in the presale property market is serious as discussed before. This is on one hand due to developers' taking advantage from manipulating the information, on the other hand, poor transparency of market information is also resulted from slow and incomplete information issued by local governments. Furthermore, there is 
also deficiency in the real estate education (Cao, 2009) partially caused by the central government when the Ministry of Education cancelled real estate education as an undergraduate programme in 1998. Given the weak bargaining power and the costly legal proceedings, individual buyer usually could do little when dispute arises.

\section{PROBLEMS LATENT IN THE INSTITUTIONAL PROPERTY PRESALE SYSTEM}

In order to identify the major problems latent in the presale market, 120 semi-structured interviews were conducted to members of the three-level institutional hierarchy of major market players, i.e., consumers from the public representing the interest of the general presale property buyers, representatives from professional institutions and members from development companies in Shenzhen and Guangzhou. Among them, 58 consumers were invited randomly from different academic institutions to join the interviews, 27 from construction professionals and 35 from developers who were referred by different professional institutions and developers through personal contact.

The questions set out for the interviews were divided into two parts. Section A included a number of risk factors identified from the literature review with the aim to assess their importance. The respondents were asked to rank the seriousness of different types of presale risks from 1 to 5 according to the following classification:

1 - the risk was not apparent;

2 - the risk posed a problem but the degree was not serious;

3 - the risk was apparent and the impact was serious in some developments;

4 - the risk was imminent and the impact caused concern of the parties involved;

5 - the risk was imminent and the impact was very serious and caused public concern.

Section B contained open questions for examining the root of the problems and identified the critical factors affecting the development of the presale property market which included the roles of the different bodies, i.e. the government, REDA, CC and EAA, should play within the institutional system.

\section{Presale risk factors}

The overall ratings of the risk factors, ranging from 3.00 to 3.88 , showed that all the presale risks as identified in Table 1 were considered apparent in the market. Among them, deficient housing quality, delayed delivery and development default were ranked the top three most serious presale risks with an overall average rating of $3.88,3.86$ and 3.39 respectively, i.e. the risks were considered imminent and the impact caused concern of the parties involved. Although exaggeration of saleable areas, unqualified for property certificates and the use of unethical presale tactics were considered less serious, the ratings were considered high at $3.20,3.17$ and 3.07 , i.e. the risks were apparent and the impacts were serious in some developments. Features mismatch was being rated the least serious but the score was also high at 3.00. Regarding the ratings given by different interest groups, they were not much different ranging from 2.82 to 4.03 which showed that the views shared among different stakeholders in regard to the risks were similar. Besides ranking of different types of presale risks, a number of interesting and distinctive insights were also gathered from the interviews which are discussed in the following sections.

Deficient Housing Quality. It was interesting to find that not only consumers but also developers considered deficient housing quality of presale properties the most serious problem in the market at a rating close to 4 , with that of professionals at a slightly lower rating of 3.62. Many developers in Mainland China opted for a low-cost strategy and therefore the quality of the developments was always found substandard, in particular, in presale properties as buyers were not able to inspect the properties before purchase. Moreover, it was a common phenomenon that developers who undertook several projects concurrently but with limited funding had to lower the costs by using 
Table 1. Rating of the seriousness of the risk factors by different interest groups

\begin{tabular}{llllll}
\hline Rating & Risk factor & Consumers & Professionals & Developers & Overall \\
\hline 1 & Deficient housing quality & 3.98 & 3.62 & 4.03 & 3.88 \\
2 & Delayed delivery & 3.92 & 3.65 & 4.01 & 3.86 \\
3 & Development default & 3.11 & 4.01 & 3.06 & 3.39 \\
4 & Exaggeration of saleable areas & 3.76 & 2.82 & 3.01 & 3.20 \\
5 & Unethical presale tactics & 3.61 & 2.85 & 3.05 & 3.17 \\
6 & Unqualified for House Certificate & 3.21 & 3.09 & 2.91 & 3.07 \\
7 & Features mismatch & 2.98 & 2.87 & 3.15 & 3.00 \\
\hline
\end{tabular}

inferior materials and cheapest workmanship in order to keep all projects going. It is stipulated in the Application of Laws Concerning Commercial Housing Contract that buyers are entitled to request for termination of the contract and compensation if sub-standard quality from the building is found. However, proof of sub-standard quality must be validated by an authorized person, and the buyer must be prepared for the time and effort to go through the long-judicial process. Although presale property carries warranty period, it is not always effective especially with small developers. Incidents showed that rectification works were often delayed until the warranty period expired in an attempt to avoid the liability.

Delayed Delivery. The ratings on delayed delivery from different stakeholders were similar to that of deficient quality which reflected that the risk of delayed delivery was considered serious and caused concern. According to the interviews, there were two main reasons attributed to the problem of delay apart from bad weather. In order to promote an early-sale of the buildings, developers often adopted a tight construction schedule which was difficult to meet. Furthermore, the fitting of electricity, water supply and other building services had to be undertaken by assigned sub-contractors, utility companies and the property company. The delay of completion was very often caused by late arrangement of the fittings with different parties of the works. If disputes arose among them, further delay would be caused. Although it was stipulated in the presale contract that buyers were entitled for compensation for the delay, in reality, developers often denied their responsibility through loopholes since the compensation terms contained in the contract were vague without stating clearly the penalty involved. There were cases in which the buyers gave up the claims because they did not have the time and resources to support a lawsuit against the giant developer.

Development Default. Both consumers and developers gave development default a rating close to 3 which showed that the risk was apparent in the market and serious in some developments. It was surprising that the rating given by professionals was even higher. From the information collected, the slack of capital custody was the undermining problem of the development default. It is mandatory that a designated local authority should be responsible for overseeing the use of the proceeds collected in accordance with the Administration of the Presale of Urban Commodity Procedures, however, the amount is restricted to the deposits taken in the preliminary sales and purchases only. Furthermore, details on the administration of the use of proceeds and the penalty imposed on mis-behaved developers are not stated in the legislation. Although more stringent requirements on capital custody are exercised in areas such as Chongqing, Guangdong and Jinan in which the capital custody are overseen by an assigned bank or an appointed construction supervision company, the measures are not unified (Wong et al., 2004).

Exaggeration of Saleable Areas. Most respondents regarded the problem apparent in the market at an overall average rating of 3.2 , and it was particularly serious in some devel- 
opments. The root of the problem was attributed to the lack of a standard measurement on floor areas and the descriptions contained in presale brochures in regard to floor areas were often misleading. It is the practice in the industry that the measurement of saleable areas consists of two parts: the internal floor area of the unit and the apportionment of the common areas. Developers tried to exaggerate the saleable areas by boosting the common areas in order to raise the house prices. The efficiency rate of the usable floor area of residential properties lately built was getting lower in between $70 \%$ and $80 \%$. Although it is mandatory in the presale contract that compensation must be rendered to buyers if the saleable area of the complete property differs from what is stated in the contract by a variation of over $3 \%$, the compensation has never been rendered due to lack of a standard measurement rule.

Unethical Presale Tactics. In regard to the use of unethical presale tactics, most consumers considered the problem serious and caused public concern with an average rating of 3.6, whereas both developers and professionals also considered the problem apparent and particularly serious in some developments. For example, misleading information was contained in presale promotion materials to exaggerate the quality of the buildings, presales of uncompleted properties without Presale Permit, inaccurate price list and transaction information were given. Even worse, there were cases where the potential buyers were provided with false information on the mortgage arrangement and, at the end, they were not able to get a mortgage after the presale deal was closed. Some unscrupulous developers even repeatedly presold the same property to several buyers (Wang, 2005). According to Article 13 of the Administration of the Presale of Urban Commodity Procedures, a fine will be imposed if developers conducted the presales without meeting the prescribed rules and regulations. However, the fine of less than 1\% of the proceeds collected or not exceeding RMB30,000 is just too little to deter the mal-practices of developers. From the interview, Vice President of CCREA, Guangzhou, Mr. Pan Shujian, remarked that he had never heard of any developers being punished because of mal-practices in conducting property presales.

Unqualified for House Certificate. Most respondents from different stakeholders considered the risk apparent, and this was particular serious in small-scale developments. There were three common phenomena for developers not being able to get a House Certificate as follows:

1. the houses were built on CollectivelyOwned Land;

2. the completed properties could not get the Certificate of Completion Acceptance;

3 . the houses were repeatedly sold or mortgaged.

The houses being sold or mortgaged repeatedly were found as one of the main reasons of House Certificates not being granted. On the other hand, $71 \%$ of the respondents believed that those houses which could not get the Certificate of Completion Acceptance because they were not well-equipped to get through the examinations such as protection against fire and structural problems. It was also interesting to find that some developers intentionally failed to apply for the Certificate of Completion Acceptance in some cases. When the housing market was in a surge, developers tried all means to induce the buyers to give up their presales so that developers could re-sell the properties at a higher price in the market. In regard to houses built on Collective Land, most respondents attributed the problem to the lack of information available in the market for public scrutiny. It should be noted that in Mainland China, Collective Land means the land that is collectively owned by rural collective economic organizations. These lands are not allowed for commercial purpose until they have been converted into state-owned land. Hence, houses built on Collective Land can never be able to get the House Certificate for transfer of the property rights.

Features Mismatch. The problem of features mismatch was ranked the lowest among all the presale risks identified with an overall 
average rating of 3 . Respondents from all the 3 different groups of stakeholders regarded the problem as apparent, but it was serious in only some developments. In Mainland China, most houses were used to sell with only basic features in form of adobe houses and, therefore, features mismatch would not be a problem on presales of adobe houses. However, developers started to offer decoration with extra fittings and fixtures in selling properties in recent years to attract prospective buyers. It was not uncommon that the features and fittings turned out to be different from what had been promised such as the brands, types and quality of floor tiles, door panels and locks, sanitary sets and others. Some developers in Shenzhen charged a low price to promote their houses with decoration. However, the decoration quality was so inferior that, for example, the expected wooden floor tile was replaced by leatheroid. Despite the Detailed Rules for Implementation of Decorating Commodity House was issued by the Ministry of Construction in 2002, mismatch of fittings and features were often found.

\section{ROOT OF THE PROBLEMS IN THE PRESALE PROPERTY INSTITUTION}

Upon examination of the institutional system and the information collected from the survey in regard to property presales, the root of the problems latent hindering the operation of the market can be attributed to the following:

Opaque market information. $73.4 \%$ respondents from the survey found that the opaque presale market information is the most serious problem. For example, no measure has been taken by the government or the CCA to publicize the transaction information of property presales, nor the information about the house price, house areas and the facilities. Furthermore, the government has done little in mitigating the asymmetric information problem in the market and, with biased information, the sense of contract bonding in the market is weak. Furthermore, the use of the proceeds collected from the presales is not transparent.
An independent credit system overseeing the proceeds collected has been set up recently but its effectiveness is yet to assess.

Pseudo policy objectives of governments. Despite a series of policies have been undertaken to formalize the presale procedures, the authorities tend to favor developers in the policy-making and have not been fully committed to enforcing the measures to safeguard the rights of presale property buyers. It is largely due to the fact that the real estate market has made a significant contribution to the GDP and tax revenues required for running the government. In 2007, the real estate market contributed $5.82 \%$ of the total GDP in Mainland China, and the land revenue also accounted for more than $50 \%$ of the total government revenue. Furthermore, the economic growth of the area is treated as part of the performance index of the local authority, the higher the growth of the real estate market in the area often symbolizing the better performance of the local officials.

Confusing roles of market players. Regarding the role of CCREA and CCA, they are only self-regulatory institutes who are responsible for reflecting the complaints of consumers such as contract deceits and false advertisements to the related parties and the governmental departments. However, they do not possess any legislative power to enforce developers to comply with the guidelines in conducting presales. In reality, CCREA provides guidelines primarily aim at protecting the interests of its developer members. There were also incidents that CCA was being pressured to hide information which were unfavorable to developers.

\section{CRITICAL FACTORS FOR THE DEVELOPMENT OF THE PRESALE MARKET}

Important insights were also drawn from the study to identify the set of factors critical to the development of the institutional system of property presales in Mainland China which are discussed as follows: 
Financing means. So far, the finance for most real estate developments in China is restricted to bank loans and upfront capital from presales. In order to control the credit risks, it is necessary to expand the financial channels through product innovation. The development of Real Estate Investment Trusts (REIT) started in the Mainland China in recent years and the channel through asset- and mortgagebacked securitization is not available. The lack of a well established real estate finance market pushes developers to higher financial difficulties and thus development default would also be higher. Only with innovation of real estate financial means can help channel funds from the institutional investors to support a sustainable development of the real estate industry (Xu and Yang, 2006).

Risk management on presale proceeds. To protect the proceeds collected from presale property buyers, different countries set up different systems over the custody of the funds, for example, Financial Performance Guarantees for escrow in America, The Estate Transaction Guarantee System set up in Japan, and the Housing Implementation and Guarantee System in Thailand. Similar escrow system should also be set up in China in which a financial institution as the trusted third party should be appointed to act as the custodian overseeing the funds deposited in the bank. The power of the custodian must also be limited to release to the developer only the sum certified by the authorized person as having been expended on the building. The third party should be responsible for monitoring the cash flow direction, use of funds, project's development conditions and releasing the escrowed capitals to developers when reaching the escrow requirement. As such, the custody of the funds could be jointly controlled by the custodian, the bank and the authorized person.

Risk management on developers. Credibility of developers is of utmost importance to the risk management in real estate development in China and the transparency of the finance management of borrowers is a definite step to risk management. Banks should possess the credit position of the developers and the progress of the project development for exercising an effective risk management. Possessed with the information, the credibility of the developers can be classified and different credit policies can be imposed in accordance with their credit rating. Furthermore, the banks should monitor and control the mortgage applicants who have applied for multiple mortgages and a credit record system containing the credit history of developers and details of the real estate developments must be set up. The system should also contain the transaction records of the development and the details of mortgage applications. An efficient presale property market can be achieved only if the market information can be enhanced.

Commitment of the regulatory departments. Commitment of the government to safeguard the rights of presale property buyers is of utmost importance for a sustainable development of the presale property market. Rules and regulations have been laid out in various Law and Procedures such as the Administration of the Presale of Urban Commodity Premises. The local authorities should strictly adhere to the rules and make the regulations enforceable. Any unethical and illegal presale practices should be punished in accordance to the penalties stipulated and the magnitude of the penalties should be high enough to deter developers from unethical practices. In the mean time, the terms of the presale contract should also be standardized in order to prevent presale purchasers from falling into the contract traps made by unscrupulous developers. If necessary, Risk Insurance Fund should be enforced to assure that once presale risks occurred, the fund could be used to compensate the presale property buyers. CCA should publicize the related policies and help consumers understand the contents. Moreover, CCA should promulgate the set of guidelines to educate consumers the important issues to note, how to look for the relevant information and how to safeguard their rights in a purchase of a presale property. 


\section{CONCLUSIONS}

Presales of uncompleted properties have been the major financing mode for real estate developments in Mainland China. However, the problems generated from information asymmetry in the presale property market have caused public concern. Adapting the institutional approach by examining the administration and regulatory system employed in the market, the financing system and the roles played by different market stakeholders including the central government, local authorities, developers and consumers, the root of the problems latent in the market have been identified. They include the pseudo policy objectives pursued by both the central government and local authorities which render the laid-down rules and regulations ineffective, the confusing roles played by the market participants of CCREA and CCA which undertaking regulatory measures with no enforcing power, and the lack of information transparency in the market. In order to enhance the efficiency of institutional system for the presale property market, attention should be focused on expanding the channels of financing for real estate development, risk management on both the creditability of development as well as custody on presale proceeds collected. Last but not the least, commitment of the government to uphold the rules and regulations and to safeguard the rights of presale property buyers is of utmost importance for the long-term sustainable development of the presale property market.

\section{ACKNOWLEDGEMENT}

This research was funded by the Department of Building and Real Estate, The Hong Kong Polytechnic University (Grant No. 1-ZV4Y).

\section{REFERENCES}

Brown, G. R. and Matysiak, G. A. (2000) Real estate investment - a capital market approach. Prentice Hall.

Buang, S. (2006) Housing heartaches, Property Malaysia, 26 April.
Buttimer, R. J., Clark, S. P. and Ott, S. H. (2008) Land development: risk, return and risk management, Journal of Real Estate Finance and Economics, 36(1), pp. 81-102. http://dx.doi.org/10.1007/s11146007-9077-z

Cao, J. A. (2009) Developmental state, property-led growth and property investment risks in China, Journal of Property Investment \& Finance, 27(2), pp. 162-179. http://dx.doi.org/10.1108/14635780910937854

Cao, X. L., Yang, J. G. and Jiang, X. H. (2008) Commercial housing presale risks analysis and management at the perspective of purchasers, Journal of Shan Xi Architecture, 34(9), pp. 237-238.

Chan, S. H., Fang, F. and Yang, J. (2008) Presales, financing constraints, and developers' production decisions, Journal of Real Estate Review, 30(3), pp. 345-375.

Chau, K. W., Wong, S. K. and Yiu, C. Y. (2007) Housing quality in the forward contracts market, Journal of Real Estate Finance \& Economics, 34(3), pp. 313325. http://dx.doi.org/10.1007/s11146-007-9018-x

Choy, L. H. T. and Chau, K. W. (2006) Pricing under asymmetrical information - a case study on Hong Kong's housing market. In: Proceedings from the $12^{\text {th }}$ Annual Conference of the Pacific Rim Real Estate Society, 22-25 January, 2006, Auckland, New Zealand.

Coase, R. (1998) The new institutional economics, American Economic Review, 88(2), pp. 72-74.

D’Arcy, E. and Keogh, G. (1997) Towards a property market paradigm of urban change, Environment and Planning A, 29(4), pp. 685-706.

D’Arcy, E. and Keogh, G. (1998) Territorial competition and property market process: an exploratory analysis, Urban Studies, 35(8), pp. 1215-1230. http:// dx.doi.org/10.1080/0042098984330

Gao, Z. Z. (2007) A practical legal guide to PRC real estate investment. China Citic Press.

JRJ (2011) Various news on petty title properties in Beijing, JRJ. [Online] Available at: http://finance.jrj. com.cn/house/2011/12/29021411934350 [accessed 18 July 2011]

Kalifa, A. M. (2005) Room for change-tighter controls needed to shape up China's property presale system, BuroBiz Magazine, November 2005.

Keogh, G. and D’Arcy, E. (1999) Property market efficiency: an institutional economics perspective, $U r$ ban Studies, 36(13), pp. 2401-2414. http://dx.doi. org/10.1080/0042098992485

Lai, R., Wang, K. and Zhou, Y. (2004) Sale before completion of development: pricing and strategy, Real Estate Economics, 32(2), pp. 329-357. http://dx.doi. org/10.1111/j.1080-8620.2004.00094.x

Leung, Y. P. B., Hui, C. M. E. and Seabrooke, B. (2007a) Asymmetric information in the Hong Kong forward property market, International Journal of Strategic Property Management, 11(2), pp. 91-106. http://dx.doi.org/10.1080/1648715X.2007.9637563

Leung, Y. P. B., Hui, C. M. E. and Seabrooke, B. (2007b) Pricing of presale properties with asymmetric infor- 
mation problems, Journal of Real Estate Portfolio Management, 13(2), pp. 139-152.

Leung, Y. P. B. (2010) Wealth transfer in forward property markets, International Journal of Strategic Property Management, 14(3), pp. 258-270. http://dx.doi. org/10.3846/ijspm.2010.19

Leung, B. Y. P., Hui, E. C. M., Tan, J. H., Chen, L. and $\mathrm{Xu}, \mathrm{W}$. B. (2011) SWOT dimensional analysis for strategic planning - the case of overseas real estate developers in Guangzhou, China, International Journal of Strategic Property Management, 15(2), pp. 105-122. http://dx.doi.org/10.3846/164871 5X.2011.582745

Lisheng, D., Christensen, T. and Painter, M. (2010) Housing reform in China: rational interests gone wrong or organizational design failure?, Journal of Asian Public Policy, 3(1), pp. 4-17. http://dx.doi. org/10.1080/17516231003634120

North, D. C. (1990) Institutions, institutional change, and economic performance. Cambridge University Press.

North, D. C. (2005) Understanding the process economic change. Princeton University Press.

Research in China (2008) Capital for real estate development, Real estate web report. [Online] Research in China. Available at: http://www.researchinchina. com/news [assessed 21 December 2011]

Tang, B. S., Wong, S. W. and Liu, S. C. (2006) Property agents, housing markets and housing services in transitional urban China, Housing Studies, 21(6), pp. 799823. http://dx.doi.org/10.1080/01436590600917647

TBW (2010) The trail to cancel presale proceeds in Nanning. [Online] The Beijing News. Available at: http:// news.163.com/10/0124/04/5TP341FR0001124J.html [assessed 12 January 2012]
Wang, F. (2005) Research on the risks and mitigation ways of the forward commercial premises, Real Estate Information of China, 10, pp. 17-19.

Wang, W. C. (2008) Research on the evolution mechanism and related regulation policy of China's real estate price. Jilin University.

Wang, H. Y. and Chen, Y. M. (2010) Research on China real estate legal responsibility. In: Ng, L. F. (Ed.) Government-led administration and corporate social responsibility of real estate developers. Chung Shan University Press.

Whitehead, C. M. E. (1983) The rationale for government intervention, Urban Land Policy: Issues and Opportunities, pp. 108-129.

Wong, K. W. F., Seabrooke, W., Wong, K. C., Hung, K. N., Lau, W. N., Liu, H. Y. and Ruan, X. J. (2004) Market potential for Hong Kong professionals in the mainland China. Researh Monograph. The Hong Kong Polytechnic University.

Wong, M. (2012) The challenges of doing real estate in Mainland for foreign developers - a practitioner's perspective. In: Seminar PowerPoint, Network for New Institution Urban Studies (NIUS), The Hong Kong Polytechnic University, Hong Kong, China. 13 January, 2012.

Xu, Y. M. and Yang, X. (2006) Thinking on commodity premises presale system, Chongqing Architecture, 7, pp. 132-134.

Zhong, J. (2005) Commercial presale institution and its main features in various countries and districts, China Real Estate Market, October Issue, pp. 44. 